Abstracta Iranica Iranica

Revue bibliographique pour le domaine irano-aryen

Volume 32-33 | 2013

Comptes rendus des publications de 2009-2010

\title{
Fabrizio Speziale. Muslim or Greek? Past and Present of Yunani Medicine in the Deccan
}

\section{Anna Vanzan}

\section{(2) OpenEdition}

12 Journals

\section{Electronic version}

URL: http://journals.openedition.org/abstractairanica/40725

DOI: 10.4000/abstractairanica.40725

ISSN: 1961-960X

Publisher:

CNRS (UMR 7528 Mondes iraniens et indiens), Éditions de l'IFRI

\section{Printed version}

Date of publication: 1 December 2013

ISSN: 0240-8910

\section{Electronic reference}

Anna Vanzan, «Fabrizio Speziale. Muslim or Greek? Past and Present of Yunani Medicine in the Deccan », Abstracta Iranica [Online], Volume 32-33 | 2013, document 406, Online since 01 July 2016 connection on 26 September 2020. URL : http://journals.openedition.org/abstractairanica/40725 ; DOI : https://doi.org/10.4000/abstractairanica.40725

This text was automatically generated on 26 September 2020 .

Tous droits réservés 


\title{
Fabrizio Speziale. Muslim or Greek? Past and Present of Yunani Medicine in the Deccan
}

\author{
Anna Vanzan
}

\section{REFERENCES}

Fabrizio Speziale. « Muslim or Greek? Past and Present of Yunani Medicine in the Deccan », in : Rais Akhtar \& Nilofar Izhar, eds., Global Medical Geography. In Honour of Prof. Yola Verhasselt. Jaipur-New Delhi, Rawat Publication, 2009, p. 305-332.

1 This article analyzes the main aspects of Muslim medical learning in the Deccan, India, where many Persian medical treatises were written prior to the 19th century. The development of medical learning under the Deccan Sultanates is examined, especially under the Quṭb Šāh of Golconda and Hyderabad (16th and 17th centuries) who employed several physicians of Iranian origin at their court. The article also describes the important medical reforms enacted during the 20th century, under the last Nizāms and, later, after Indian independence, that reshaped the scientific identity of yūnāni learning and institutions by modernizing many of traditional features.

\section{AUTHORS}

ANNA VANZAN

Italie 